\title{
Interdisciplinarity and nursing research: opportunities and challenges
}

\author{
Interdisciplinaridade e pesquisa em enfermagem: oportunidades e desafios \\ La interdisciplinariedad y la investigación en enfermería: oportunidades y desafíos
}

\author{
Franco A. Carnevale \\ 'McGill University, Ingram School of Nursing. Montreal, Canada.
}

Submissão: 02-10-2014 Aprovação: 02-10-2014

\begin{abstract}
Interdisciplinary collaboration is widely recognized and considered essential for optimizing the development of knowledge and practice. However, interdisciplinarity is commonly accepted as an unquestioned good; rarely examined as both a source of benefit as well as difficulty for nursing and other disciplines. The aim of this article is to critically examine the opportunities and challenges that interdisciplinarity can provide for research in nursing and other disciplines. Based on a North American perspective, I describe the emergence of uni-disciplinary nursing research and the knowledge exchanges that occurred between nursing and other disciplines. I discuss the rise of interdisciplinary research, outline several examples of nursing participation in interdisciplinarity, and highlight the prominent benefits and difficulties associated with interdisciplinary research. I argue that authentic collaboration is required to conduct meaningful interdisciplinary research and describe how this can be promoted.
\end{abstract}

Key words: Interdisciplinary; Nursing; Research; Collaboration.

\section{RESUMO}

Colaboração interdisciplinar é amplamente reconhecida e considerada essencial para a otimização do desenvolvimento do conhecimento e prática. No entanto, a interdisciplinaridade é comumente aceita como um bem inquestionável, raramente examinado tanto como uma fonte de benefícios, bem como dificuldade para a enfermagem e outras disciplinas. O objetivo deste artigo é analisar criticamente as oportunidades e desafios que a interdisciplinaridade pode oferecer para a pesquisa em enfermagem e outras disciplinas. Com base em uma perspectiva norte-americana, descreve-se o surgimento de pesquisas em enfermagem unidisciplinar e as trocas de conhecimento que ocorreram entre a enfermagem e outras disciplinas. Discute-se a ascensão da pesquisa interdisciplinar, delineiam-se vários exemplos de participação da enfermagem na interdisciplinaridade, e destacam-se os benefícios proeminentes e dificuldades associadas com a pesquisa interdisciplinar. Defende-se que a colaboração autêntica é necessária para conduzir a pesquisa interdisciplinar significativa e descreve-se como isso pode ser promovido.

Descritores: Interdisciplinaridade; Enfermagem; Investigação; Colaboração.

\section{RESUMEN}

La colaboración interdisciplinaria es ampliamente reconocida y considerada esencial para optimizar el desarrollo del conocimiento y la práctica. Sin embargo, la interdisciplinariedad es comúnmente aceptada como un bien incuestionable; rara vez examinada tanto como una fuente de beneficio, así como de dificultad para la enfermería y otras disciplinas. El objetivo de este artículo es examinar críticamente las oportunidades y desafíos que la interdisciplinariedad puede proporcionar para la investigación en enfermería y otras disciplinas. Sobre la base de una perspectiva norteamericana, describe-se el surgimiento de la investigación en enfermería unidisciplinaria y los intercambios de conocimientos que se produjeron entre la enfermería y otras disciplinas. Se discute el aumento de la investigación interdisciplinaria, esbozan-se varios ejemplos de la participación de enfermería en la interdisciplinariedad, y destacan-se los beneficios y las dificultades asociadas con la investigación interdisciplinaria. Argumenta-sé que se requiere auténtica colaboración para llevar a cabo la investigación interdisciplinaria significativa y describe-se la forma en que esto puede ser promovido.

Palabras clave: Interdisciplinaridad; Enfermería; Investigación; Colaboración. 


\section{INTRODUCTION}

Interdisciplinary collaboration in research and in practice has become widely recognized and is considered essential for optimizing the development of knowledge and practice ${ }^{(1-2)}$. However, interdisciplinarity is commonly accepted as an unquestioned good; rarely examined as both a source of benefit as well as difficulty for nursing and other disciplines.

The aim of this article is to critically examine the opportunities and challenges that interdisciplinarity can provide for nursing research. This discussion focuses predominantly on trends and examples in North America - the setting that I know best - but highlights themes that can be relevant in other settings (e.g., Brazil).

\section{UNDERSTANDING THE HISTORICAL CONTEXT}

To critically examine the opportunities and challenges that interdisciplinarity can provide for nursing research, it is important to see how the development of nursing research has intersected with other disciplines in the past. This highlights benefits and difficulties that nursing and other disciplines have negotiated over the years, leading to the present research environment.

Professional and academic nursing, as it is currently recognized in North America, emerged in the mid-1900s ${ }^{(3)}$. During the 1950s and 1960s, there were significant initiatives to develop standards for nursing education, particularly within university programs. This sparked an unprecedented explosion of writings on defining nursing as a professional discipline as well as articulations of the scope of practice and the body of knowledge for the discipline. Many thinkers developed frameworks, models, or grand theories on nursing, which would help orient the development of nursing education curricula as well as nursing practice. Some nursing leaders undertook doctoral education in other disciplines, as doctoral nursing studies had not yet been developed. Many of these leaders pursued their doctoral studies in education, as they were nursing educators themselves. In 1952, the journal Nursing Research was launched. Understandably, the initial focus of empirical research conducted in nursing was on nursing education.

During the 1960s, nursing researchers gradually turned their attention to clinical research, studying health problems in patients and families ${ }^{(3)}$. This marked the beginning of clinical nursing research. Additional nursing research journals continued to emerge. Throughout the 1960s and 1970s, nursing leaders continued to produce publications to further define the body of knowledge of nursing; which also helped define directions that should be followed by clinical nursing research.

Some of the seminal early publications, among many others, that significantly helped advance understandings of the scope and the nature of nursing knowledge included: (a) Carper's (in 1978) identification of empirical, esthetic, personal, and ethical patterns of knowing in nursing ${ }^{(4)}$; (b) Fawcett (in 1984) who proposed a metaparadigm for nursing based on the four foundational concepts health, person, environment, and nursing ${ }^{(5)}$; and (c) Benner (in 1984) who uncovered the complexity of nursing practice by demonstrating the progression of the development of clinical nursing expertise from novice to expert ${ }^{(6)}$.

\section{KNOWLEDGE EXCHANGES BETWEEN DISCIPLINES}

Throughout this early development of nursing as a scholarly and research discipline, building on its longstanding recognition as a practice discipline, nursing drew heavily on existing knowledge from other disciplines that intersected with the scope of nursing. This included substantive as well as methodological knowledge ${ }^{(3)}$.

For example, the substantive knowledge base of nursing was developed by adapting knowledge about: (a) human anatomy, physiology, pathology (biological sciences); (b) physical assessment, use of the sphygmomanometer and thermometer, venipuncture (medical science); (c) drug action (pharmacology); (d) drug administration (pharmacy); (e) stress and coping (physiology, psychology); (f) pain (physiology, pharmacology, psychology); (g) family systems and functioning (psychology, family therapy); (h) learning theories (psychology, education); (i) social theories and concepts (sociology, philosophy, critical and feminist studies); (j) professional ethics (philosophy, law, bioethics); among many others.

Examples of methodological knowledge that nursing adapted from other disciplines included: quantitative methodologies (medical sciences, epidemiology, psychology, statistics); as well as various qualitative methodologies such as grounded theory (sociology), ethnography (anthropology, sociology), phenomenology and hermeneutics (philosophy); among many others.

Over time, nursing knowledge developed in directions that led to innovative contributions and influence in the development of knowledge in other disciplines. Examples of nursing knowledge that was adapted by other disciplines included: qualitative methodologies for health research; shifting the focus of care from disease and illness to health; 'holistic' or 'bio-psycho-social' conceptions of health; stress and coping as it related to various health problems; family-centered conceptions of health care; comprehensive multi-dimensional conceptions, assessment, and treatment of pain; assessment and care of pressure ulcers; mouth care; among many others.

\section{EMERGENCE OF INTERDISCIPLINARY COLLABORATION}

The knowledge exchanges between disciplines described above were predominantly uni-disciplinary in nature. That is, individual researchers or groups of researchers within individual disciplines, such as nursing, developed research within that discipline by adapting knowledge from other disciplines; without seeking to bridge ideas to build common knowledge across disciplines. In some research, researchers from other disciplines (e.g., statisticians, psychologists of pain) were consulted or invited to join nursing research teams, but the overall aims of the research was centered on the development of nursing knowledge.

Toward the end of the twentieth century, collaboration across disciplines became gradually recognized as important and eventually as necessary for ensuring the optimal development of knowledge $^{(1-2)}$. Some research teams led the way by demonstrating the significant intellectual synergies and transformations of understanding that could be produced through meaningful collaborations among diverse disciplinary perspectives. 
The merits of interdisciplinary collaboration have also been demonstrated for the development of optimal clinical practices through initiatives in inter-professional education. The latter involves the development of some common curriculum for the health professions to promote exchanges among students and faculty from different professions - to help build inter-professional collaboration early in the learning and socialization of students. Outcomes research has demonstrated that inter-professional collaboration leads to improved patient outcomes ${ }^{(7)}$.

There has been some debate about how these research collaborations should be construed: multidisciplinary, transdisciplinary, or interdisciplinary. 'Inter'-disciplinary is largely recognized as the most favored term, as it conveys an orientation toward knowledge integration rather than sharing or exchanging.

In some areas, interdisciplinary research has stretched beyond the development of interdisciplinary teams to the creation of genuinely interdisciplinary research domains that are no longer affiliated with any single discipline. Nursing has participated in, contributed to, and drawn from many of these interdisciplinary fields of inquiry. Examples of these include: women's studies; cultural studies; disability studies; childhood studies.

To illustrate, childhood studies commonly involves the collaboration of many disciplines interested in different aspects of childhood including anthropology of childhood, sociology of childhood, child law, childhood education, philosophy of childhood, child psychology, childhood social services, children's art and literature, and pediatric health sciences (e.g., nursing, medicine $)^{(8)}$. An internationally renowned example is the Rutgers-Camden Center for Children and Childhood Studies (for information see http://children.camden.rutgers.edu/).

\section{Some examples of interdisciplinarity with nursing participation}

For the purposes of illustration, I have outlined some examples from our own research work to demonstrate various areas in which nursing can contribute to and benefit from participation in interdisciplinary research. In selecting our own research, I am not implying that these are the best examples of interdisciplinarity. Rather, I have selected these because I know them well, and can knowledgeably discuss the opportunities and challenges that these implied for nursing.

Pain in Child Health: This international research program is designed to promote interdisciplinary training for graduate students ${ }^{(9)}$. The training aims to build interfaces between disciplines with an interest in pain. Participating disciplines include: biology, genetics, pharmacy, psychology, bioethics, nursing, medicine, rehabilitation sciences (physiotherapy and occupational therapy), and statistics.

Children with complex care needs: This research team has investigated various ethical problems confronted by children with complex care needs (this population is sometimes referred to as 'children with special health care needs') and their families ${ }^{(10-11)}$. This work has drawn on a disability studies model to ensure the development of a rich understanding of the moral domain of the lives of these children and families. Participating disciplines have included: nursing, medicine, respiratory therapy, bioethics, law, disability studies, rehabilitation sciences, and sociology.
Grounded theory study of meta-analysis: This investigation examined the analytical reasoning used by researchers conducting a meta-analysis, confronting ideas from epistemology and the social sciences with conventional data aggregation approaches used in health sciences research ${ }^{(12)}$. Disciplines that participated in the research included: nursing, medicine, epidemiology, statistics, and anthropology.

Interdisciplinary studies of childhood ethics: This team has been examining ethical concerns in childhood as well as practice changes required to address these concerns ${ }^{(13)}$. Multiple disciplines have helped ensure that this research investigates childhood from a variety of perspectives to advance a comprehensive understanding of these ethical concerns. For example, we have sought to better understand children as persons, patients, students, citizens, victims, and aggressors (e.g., bullies). Disciplines in this team include: pediatric health sciences (nursing and medicine), childhood education, child psychology, child law, social sciences, social services, bioethics, disability studies, and philosophy of childhood. This research is being conducted in Brazil as well(14).

Cultural competency education: Educational strategies for promoting cultural competency in the health professions were developed and assessed, using an inter-professional education model ${ }^{(15)}$. Disciplines that participated in the research included: nursing, medicine, anthropology, and educational psychology.

Philosophical problems in the health sciences: This team worked to demonstrate the merits of developing hermeneutical approaches to examining foundational problems in the health sciences; specifically epistemological, ontological, moral, and political problems ${ }^{(16)}$. Participating disciplines included: philosophy, bioethics, nursing, medicine, psychology, and social sciences.

Participant observation with children: Ethical challenges in conducting participant observation with children were examined to develop strategies that address these concerns without compromising the methodological strength of the study ${ }^{(17)}$. This included participation from: nursing, bioethics, sociology, and anthropology.

Ethical problems in pediatric critical care: This research has examined ethical problems in pediatric critical care, using international comparative designs ${ }^{(18-20)}$. This has included: nursing, medicine, psychology, and bioethics.

Moral distress in pediatric critical care: This team investigated moral distress experienced by health professionals caring for critically ill children, using narrative inquiry ${ }^{(21)}$. This included: nursing, medicine, bioethics, and sociology.

\section{INTERDISCIPLINARY RESEARCH: OPPORTUNITIES AND CHALLENGES FOR NURSING}

\section{Opportunities}

Many benefits have been associated with interdisciplinary research. These can provide significant opportunities for the reciprocal development of nursing and other disciplines.

Interdisciplinary research can help ensure intellectual diversity and synergy by drawing on a wide variety of scholarly perspectives while also requiring the bridging and integration of these perspectives to build common interdisciplinary knowledge. Multiple perspectives can promote the identification of diverse 
research problems and the utilization of diverse theoretical and methodological orientations. An interdisciplinary research team can help ensure more sophisticated data analyses and broader and more meaningful utilization of research knowledge.

Moreover, whereas the interdisciplinary collaboration of diverse disciplines in research can help enrich the quality of the interdisciplinary knowledge that can be produced and utilized, individual disciplines (e.g., nursing) can also be enriched as researchers from these disciplines can bring their acquired interdisciplinary insights back to their own disciplines. For example, disability studies has advanced a richer understanding of the complex interrelation between bodies, functionalities, physical and social environments as barriers and facilitators for participation in community life, social beliefs, values and practices that can include or exclude selected members of a community, as well as the assistive function that various prostheses and supportive technologies can have ${ }^{(11)}$. Nursing has contributed to this field of inquiry by drawing on the discipline's particular understanding of bodily function and personal experiences. Meanwhile, nursing can draw on this knowledge to enrich the preparation of nursing students for clinical practice and develop nursing research to examine how the nursing care of disabled persons can be optimized. Moreover, disability studies knowledge can be adapted for inter-professional education to promote more effective collaboration among nurses, physicians, physiotherapists, occupational therapists, speech pathologists, psychologists, and social workers, as these health professions can draw on common knowledge to develop more cohesive plans of care.

\section{Challenges}

Given the many significant benefits that it can promote, it is tempting to consider interdisciplinarity as solely beneficial and unquestionable. However, this would be an incomplete and misleading representation of interdisciplinarity; minimizing the difficulties that researchers can encounter, which can potentially compromise the quality of knowledge that can be produced and utilized.

Unless there is a significant investment by a collaborative team toward the development of shared understandings and research objectives, without 'homogenizing' the rich diversity of disciplinary perspectives brought to the team, a team can experience a 'Tower of Babel' phenomenon where each researcher is speaking from an incomprehensible disciplinary language. Different disciplines may draw on diverse paradigms, values, beliefs, practices, and priorities, that can at times be difficult to reconcile or may even be incommensurate. Researchers that have been socialized into and have functioned solely within uni-disciplinary perspectives may not have a developed understanding of the nature of authentic collaboration.

Drawing on a framework that I have described in an earlier publication ${ }^{(22)}$, in which I adapted ideas from Prescott and Bowen ${ }^{(23)}$, authentic collaboration implies a balanced maximization of one's views with the views of others. Collaboration is one of the five different types of relational exchanges that can develop when different persons, professions, or disciplines try to work together. In each working relationship, the participants will establish different types of balances between their respective views. Competition is a common type of working relationship. This is when a participant seeks to maximize attention to one's own views while (intentionally or unintentionally) minimizing the views of others. Accommodation refers to when a participant relinquishes one's own views and allows (or tolerates) the views of others to dominate. Avoidance describes a situation in which a participant does not promote one's own views while also discounting the views of others. Compromise refers to a situation when a participant negotiates a 'give and take' between one's own views and the views of others; to find a way for each participant to retain some aspects of his/her views while relinquishing other aspects of his/her views. Finally, as stated above, collaboration is the maximized and balanced recognition of one's own views with those of other participants in the working relationship.

Given the complexity involved in bridging diverse paradigms, values, beliefs, practices, and priorities, it is understandable that authentic collaboration is therefore very difficult to achieve in research teams. When multiple disciplinary perspectives are bought together to develop interdisciplinary research, the research team should be sensitized to these relational complexities. Activities should be undertaken to promote exchange and understanding across the diverse perspectives. The interdisciplinary team should seek to develop: (a) reciprocal respect for 'intellectual pluralism' (i.e., that there is no single superior viewpoint that should dominate over others; each viewpoint can be enriched through engaged analysis between diverse viewpoints); (b) knowledge translation across disciplines; and (c) inter-relations between research knowledge and clinical knowledge. For example, a workshop could be designed that requires each participant to describe his/her own discipline's views on a specific research problem, while the entire team works together to identify disciplinary commonalities and differences. Our own attempt to undertake this form of exchange in our interdisciplinary research on childhood ethics is illustrated in a recent publication ${ }^{(13)}$.

\section{CONCLUSION}

Nursing research should be oriented toward the promotion of the profession's societal mandate. This involves uni-disciplinary research to ensure the ongoing development of nursing knowledge and practice. However, the recent emergence of interdisciplinarity has also highlighted the benefits and the necessity of participating in interdisciplinary research. Participation in interdisciplinary research is necessary for (a) ensuring the optimal development of complex fields of inquiry where different disciplines have important but partial knowledge and (b) promoting the ongoing development of nursing knowledge and practice by adapting innovations within other disciplines and drawing on transversal integrated interdisciplinary knowledge that can shed necessary light on complex nursing concerns.

The current era of interdisciplinary research presents exciting opportunities and difficult challenges that need to be navigated to optimize the development of (a) the discipline of nursing, (b) other individual disciplines that can benefit from nursing knowledge, as well as (c) interdisciplinary domains.

This discussion of interdisciplinarity raises implications for education in the health professions, which is beyond the scope 
of this article. Educators at the basic entry-to-practice level as well as graduate studies need to examine the benefits and limitations of uni-disciplinary versus interdisciplinary curricular approaches and determine how these should be balanced. The structure and substance of these education programs will have a significant impact on the future development of interdisciplinary knowledge production and utilization discussed in this article.
A commitment to authentic collaboration from all disciplines is required to promote rich synergistic knowledge production, exchange, integration and utilization. This will ultimately help all of the collaborating disciplines to fulfill their societal mandates, while nursing also becomes more richly informed about how the profession can promote health, wellbeing, and respect for human dignity.

\section{REFERENCES}

1. Moran J. Interdisciplinarity. London: Routledge; 2001.

2. Klein JT. Interdisciplinarity: History, theory, and practice. Detroit: Wayne State University Press; 1990.

3. Meleis Al. Theoretical nursing: Development and progress. 5th ed. Philadelphia: Lippincott Williams \& Wilkins; 2012.

4. Carper BA. Fundamental patterns of knowing in nursing. Adv Nurs Sci. 1978;1(1):13-24.

5. Fawcett J. The metaparadigm of nursing: present status and future refinements. J Nurs Sch. 1984;16(3):84-9.

6. Benner P. From novice to expert: excellence and power in clinical nursing practice. Menlo Park (CA): Addison-Wesley Publishing Company; 1984.

7. Registered Nurses' Association of Ontario. Developing and Sustaining Interprofessional Health Care: optimizing patients/clients, organizational, and system outcomes [Internet].Toronto (CA): Registered Nurses' Association of Ontario; 2013 [cited 2014 February 02]. Available from: http://rnao. $\mathrm{ca} /$ sites/rnao-ca/files/DevelopingAndSustainingBPG.pdf

8. Pufall PB, Unsworth RP. Rethinking childhood. New Brunswick (NJ): Rutgers University Press; 2004.

9. Pain in Child Health [Internet]. Halifax (CA): Dalhousie University; [updated 2014 November 18; cited 2014 February 02]. Available from: http://paininchildhealth.dal.ca/.

10. Carnevale FA, Alexander E, Davis M, Rennick J, Troini $R$. Daily living with distress and enrichment: the moral experience of families with ventilator-assisted children at home. Pediatrics. 2006;117(1):e48-e60.

11. Carnevale FA, Rehm RS, Kirk S, McKeever P. What we know (and do not know) about raising children with complex continuing care needs. J Child Health Care. 2008;12(1):4-6.

12. Shrier I, Boivin JF, Platt RW, Steele RJ, Brophy JM, Carnevale $F$, et al. The interpretation of systematic reviews with meta-analyses: an objective or subjective process? BMC Med Inform Decis Mak [Internet]. 2008 [cited 2014 February 02];8(19). Available from: http://www.ncbi.nlm. nih.gov/pubmed/18495019

13. Carnevale FA, Campbell A, Collin-Vézina D, Macdonald ME. Interdisciplinary studies of childhood ethics: developing a new field of inquiry. Children Society [Internet]. 2013 [cited 2014 February 02]. Available from: http://onlinelibrary.wiley.com/doi/10.1111/chso.12063/abstract

14. Carnevale FA, Bubadué RM, Fonseca ES, Espírito Santo A, Cabral IE. Análise normativa dos padrões éticos para crianças no Brasil. Rev SORBI [Internet]. 2014 [acesso em
02 de fevereiro de 2014];2(1):35-55. Disponível em: file:///C:/Users/Cliente/Downloads/21-130-1-PB.pdf

15. Macdonald ME, Carnevale FA, Razack S. Understanding what residents want and what residents need: the challenge of cultural training in pediatrics. Med Teach [Internet]. 2007 [cited 2014 February 02];29(5):464-51.Available from: http://www.ncbi.nlm.nih.gov/pubmed/17885974

16. Carnevale FA, Weinstock D. Questions in contemporary medicine \& the philosophy of Charles Taylor: an introduction. J Med Philos [Internet]. 2011 [cited 2014 February 02];36(4):329-34. Available from: http://jmp.oxfordjournals.org/content/36/4/329.abstract

17. Carnevale FA, Macdonald ME, Bluebond-Langner $M$, McKeever P. Using participant observation in pediatric health care settings: intellectual demands and ethical solutions. J Child Health Care. 2008;12(1):18-32.

18. Carnevale FA, Canoui P, Cremer R, Farrell C, Doussau A, Seguin $M-J$, et al. Parental involvement in treatment decisions regarding their critically ill child: a comparative study of France and Quebec. Pediatr Crit Care Med [Internet]. 2007 [cited 2014 February 02];8(4):337-42. Available from: http://www.ncbi.nlm.nih.gov/pubmed/17545930

19. Carnevale FA, Benedetti M, Bonaldi A, Bravi E, Trabucco G, Biban P. Understanding the private worlds of physicians, nurses, and parents: a study of life-sustaining treatment decisions in Italian paediatric critical care. J Child Health Care [Internet]. 2011 [cited 2014 February 02];15(4):334-49. Available from: http://www.ncbi.nlm. nih.gov/pubmed/22199173

20. Carnevale FA, Farrell C, Cremer R, Séguret S, Canoui $P$, Leclerc $F$, et al. Communication in pediatric critical care: a proposal for an evidence-informed framework. J Child Health Care [Internet]. 2014 [cited 2014 February 02];18. Available from: http://www.ncbi.nlm.nih.gov/ pubmed/25038056

21. University of Alberta. The experience and resolution of moral distress in Paediatric Intensive Care Teams: a Canadian perspective [Internet]. Edmonton (CA): University of Alberta; [updated 2014 November 18; cited 2014 February 02]. Available from: http://www.picumoraldistress. ualberta.ca/en/Background/MoralDistressinthePICU.aspx

22. CarnevaleFA. Families are not visitors rethinking our relationships in the ICU. Aust Crit Care [Internet]. 2005;18(2):48-9.

23. Prescott PA, Bowen SA. Physician-nurse relationships. Ann Intern Med [Internet]. 1985 [cited 2014 February 02];103(1):127-33. Available from: http://www.ncbi.nlm. nih.gov/pubmed/4003968 